\title{
Consumer attitude and quality assessment of cooked sausages in Serbia
}

\author{
Vesna Djordjevic ${ }^{1}$,Tatjana Baltic ${ }^{1}$, Danijela Sarcevic ${ }^{1}$, Ivana Brankovic Lazic ${ }^{1}$, Jelena Ciric ${ }^{*}$
}

A b s t r a c t: The aim of this study was to determine consumer attitude and quality assessment of cooked sausages in Serbia. An eleven question survey was developed on an online survey website to analyse consumer attitude and quality assessment of cooked sausages. The questionnaire was completed by 1,959 respondents from October to December 2018. All participants were interviewed using a standardized questionnaire. The questions were related to consumption and preference for cooked sausages (hot dog, chicken frankfurters, Srpska sausages, Tirolska sausages, Pariska sausages, Ekstra sausages, Mortadella sausages and Šunkarica sausages). The results show the majority of Serbian consumers consume chicken frankfurters about once a month or less and Šunkarica sausages about once a week or less $(61.85 \%$ and $28.48 \%$, respectively). Consumers tended to strongly agree that they consume cooked sausages on any day of the week. Generally, consumers believe there are significant differences in the quality of imported and domestic cooked sausages.

Keywords: sausages, Serbia, consumption, consumer knowledge

\section{Introduction}

Consumer eating habits in Serbia suggest frequent use of cooked meat products in people's diets (Janjic et al., 2016). In the group of cooked sausages, there are a large number of products that differ by composition, the comminution grade of the stuffing, and the type and diameter of the casings. Based on the comminution grade of the stuffing, raw and cooked sausages are divided into finely chopped cooked sausages, coarsely chopped cooked sausages, cooked sausages with meat pieces and meat loaves (Vukovic, 2006). According to the current regulation on the quality of ground meat, meat preparations and meat products (Official Gazette of the Republic of Serbia, 2015; 2017), coarsely chopped cooked sausages are produced and placed on the Serbian market under the names Srpska sausage, Pariska sausage, Ekstra sausage, Tirolska sausage, Sausage of the Kranjska type, Mortadella and ham.

In addition to local products, cooked sausages from foreign markets, which consumers often consume, are also available on the market in Serbia. This affects the competitiveness of local meat industry producers. Serbian companies engaged in meat production and processing face numerous problems, such as expensive raw materials on the domestic market, constant price and livestock availability fluctuations, and serious competition from EU-based companies subsidized by their own countries. These factors have led to the fact that local meat industry companies are uncompetitive and exposed both on the domestic and world markets (Mitic et al., 2018).

The most important target for the product manufacturer is the production of competitive products with high consumer acceptance. One of the ways to achieve the set goal is to implement modern methods of sensory analysis which, in addition to the product quality evaluation, can also be successfully used for correction of its organoleptic properties according to consumer preferences. Thus, sensory examinations are carried out using the methods of consumer evaluation based on the study of consumer impressions of organoleptic characteristics of a given product (Meilgaard et al., 1999; Sarcevic et al., 2013). Various methodologies of the approach to investigating consumer preferences and analysis of the obtained results help, not only to understand the consumer attitudes toward a product, but also to reveal the main purchase motivation (Resano et al., 2009; Santa Cruz et al., 2003).

In the last few years, however, these topics have received even more attention. We are currently witnessing many debates on the quality of imported

${ }^{1}$ Institute of Meat Hygiene and Technology, Kacanskog 13, Belgrade 11000, Republic of Serbia.

*Corresponding author: Jelena Ciric, jelena.ciric@inmes.rs 
food, especially, around the presumption that imported meat and meat products are of lower quality than local products. There is no doubt that developing the meat products and processing sector will both improve the quality of food and increase the confidence of consumers (Mitic et al., 2018).

The objective of this paper was to identify the core issues affecting consumer's confidence when buying cooked sausages and to explore the impact of the same imported products on consumers' purchasing and consumption behaviour. The results of this investigation can influence the competitiveness of local meat producers on the market in Serbia.

\section{Materials and methods}

\section{Research design and sampling}

Data were collected from October to December 2018 in Serbia. The final sample included 1,959 participants. All participants consumed any of the cooked sausages (i.e. hot dog, chicken frankfurters, Srpska sausages, Tirolska sausages, Pariska sausages, Ekstra sausages, mortadella sausages and Sunkarica sausages) at least one to five times every six months. Participants were recruited randomly. They were briefly informed about the aim of the study. Data were collected with the consent of family members and from consumers who had volunteered to participate in this research. Consumers were not offered any compensation for their participation in the survey, and the obtained answers and collected data were anonymous.

In order to gain an insight into how best to construct and conduct this survey, the team met with several researchers. The questionnaire was prepared in consultation with researchers who have experience in the collecting and processing of data obtained by questionnaire. Researchers discussed the survey structure, analysed the sample questions, which had already been drafted, and the process by which the survey should be conducted.

\section{Questionnaire and scaling}

For this study, a standardized questionnaire was used in the form of an interview. The revised questionnaire was divided into three sections:

1. Demographic data of respondents (gender, age, education, dwelling, employment status, number of people in household, number of children under 10 years of age);
2. Unless otherwise specified, all the items mentioned below were measured on a five-point scale ranging from 'strongly disagree' $(=1)$ to 'strongly agree' $(=5)$. Also, consumption frequency of cooked sausages was measured. Consumer attitudes towards cooked sausages consisted of three distinct factors: (1) Cooked sausages are an important part of my family nutrition, (2) Domestic cooked sausages are of poor quality and (3) I believe that there are significant differences in the quality of imported and domestic cooked sausages.

3. Reported purchase behaviour was based on these pre-chosen factors: price, quality, colour, freshness, fat content, salt and country of origin. For each of these factors, consumers were asked to score on a 5-point scale from strongly agree to strongly disagree that it affects their purchasing decisions at retail.

\section{Statistical analysis}

Statistical analysis was elaborated using GraphPad Prism version 7.00 software. Statistical analysis was performed using Student's t-test to determine the significance of differences between means. A significance level of $\mathrm{P}<0.05$ was applied.

\section{Results and discussion}

Table 1 summarizes the sociodemographic profile of the respondents and Table 2 provides an overview of the habits of cooked sausage consumption in the respondents' households. Among the 1,959 respondents, $61.87 \%$ were males and $38.13 \%$ females. The largest proportion (45.02\%) of the interviewed householders was aged 35-49 years. Almost 37.82\% of the consumers had university undergraduate education, while $4.13 \%$ of those interviewed were employed in meat production.

The respondents' cooked sausage consumption habits/frequency in households are presented in Figure 1. The figure shows that consumers strongly agree and agree that they eat cooked sausages at any day of the week and at least once a week. Significant differences $(p<0.5)$ were found between answers.

The data presented in Figure 2 demonstrate that consumers strongly disagree that cooked sausages are important part of their nutrition. On the other hand, most consumers strongly agree there are significant differences in the quality of imported and domestic cooked sausages. The quality of cooked sausages was the primary attribute 
Table 1. Consumer characteristics ( $\%$ of respondents, $n=1,959)$

\begin{tabular}{|c|c|c|}
\hline \multirow{2}{*}{ Gender } & Female & 38.13 \\
\hline & Male & 61.87 \\
\hline \multirow{6}{*}{ Age } & $13-17$ years & 0.15 \\
\hline & $18-24$ years & 6.74 \\
\hline & $25-34$ years & 40.89 \\
\hline & $35-49$ years & 45.02 \\
\hline & $50-64$ years & 6.13 \\
\hline & $\geq 65$ years & 1.07 \\
\hline \multirow{6}{*}{ Education } & Elementary school or equivalent & 1.23 \\
\hline & High school education & 29.86 \\
\hline & Short-cycle higher education & 14.24 \\
\hline & Undergraduate & 37.82 \\
\hline & Master & 15.01 \\
\hline & $\mathrm{PhD}$ & 1.84 \\
\hline \multirow{2}{*}{ Dwelling } & City & 88.21 \\
\hline & Rural & 11.79 \\
\hline \multirow{2}{*}{ Profession (Employed in meat production) } & Yes & 4.13 \\
\hline & No & 95.87 \\
\hline \multirow{3}{*}{ Number of children in the household } & $1-6$ years & 35.07 \\
\hline & $7-14$ years & 23.43 \\
\hline & No children & 41.50 \\
\hline \multirow{4}{*}{ Number of person in the household } & 1 & 7.66 \\
\hline & $2-3$ & 48.70 \\
\hline & $4-5$ & 39.36 \\
\hline & 5 or above & 4.59 \\
\hline
\end{tabular}

Table 2. Consumption frequency of cooked sausages in Serbian household ( $\%$ of respondents, $n=1,959)$

\begin{tabular}{|c|c|c|c|c|c|c|c|c|}
\hline & \multicolumn{8}{|c|}{ Type of cooked sausages } \\
\hline & Hot dog & $\begin{array}{l}\text { Chicken } \\
\text { frankfurters }\end{array}$ & $\begin{array}{c}\text { Srpska } \\
\text { sausages }\end{array}$ & $\begin{array}{c}\text { Tirolska } \\
\text { sausages }\end{array}$ & $\begin{array}{l}\text { Pariska } \\
\text { sausages }\end{array}$ & $\begin{array}{c}\text { Ekstra } \\
\text { sausages }\end{array}$ & $\begin{array}{c}\text { Mortadella } \\
\text { sausages }\end{array}$ & $\begin{array}{c}\text { Šunkarica } \\
\text { sausages }\end{array}$ \\
\hline Never & 32.62 & 3.68 & 54.21 & 70.90 & 68.91 & 72.43 & 42.27 & 20.52 \\
\hline $\begin{array}{l}\text { Less than } \\
\text { once a month }\end{array}$ & 36.45 & 61.85 & 31.24 & 20.52 & 20.21 & 19.75 & 33.69 & 33.38 \\
\hline $\begin{array}{l}\text { Less than } \\
\text { once a week }\end{array}$ & 24.04 & 24.81 & 13.02 & 7.20 & 9.19 & 7.20 & 20.21 & 28.48 \\
\hline $\begin{array}{l}\text { At least 1-2 } \\
\text { a week }\end{array}$ & 5.30 & 6.13 & 1.23 & 1.00 & 1.50 & 0.40 & 3.52 & 14.70 \\
\hline $\begin{array}{l}\text { At least once } \\
\text { in two days }\end{array}$ & 1.59 & 3.53 & 0.30 & 0.38 & 0.19 & 0.22 & 0.31 & 2.92 \\
\hline
\end{tabular}


for consumers' buying behaviour (Figure 3). Also, Figure 3 shows the consumers perceived different factors were important when considering the purchase of cooked sausages. The majority of the consumers strongly disagreed that price is an important parameter.
In particular, in terms of sensory properties, quality and freshness were the most important factors followed by colour and salt content (Girolami et al., 2014). These attributes were also rated as the most influential in a previous study conducted on consumer liking of other cooked sausages (Mitic et

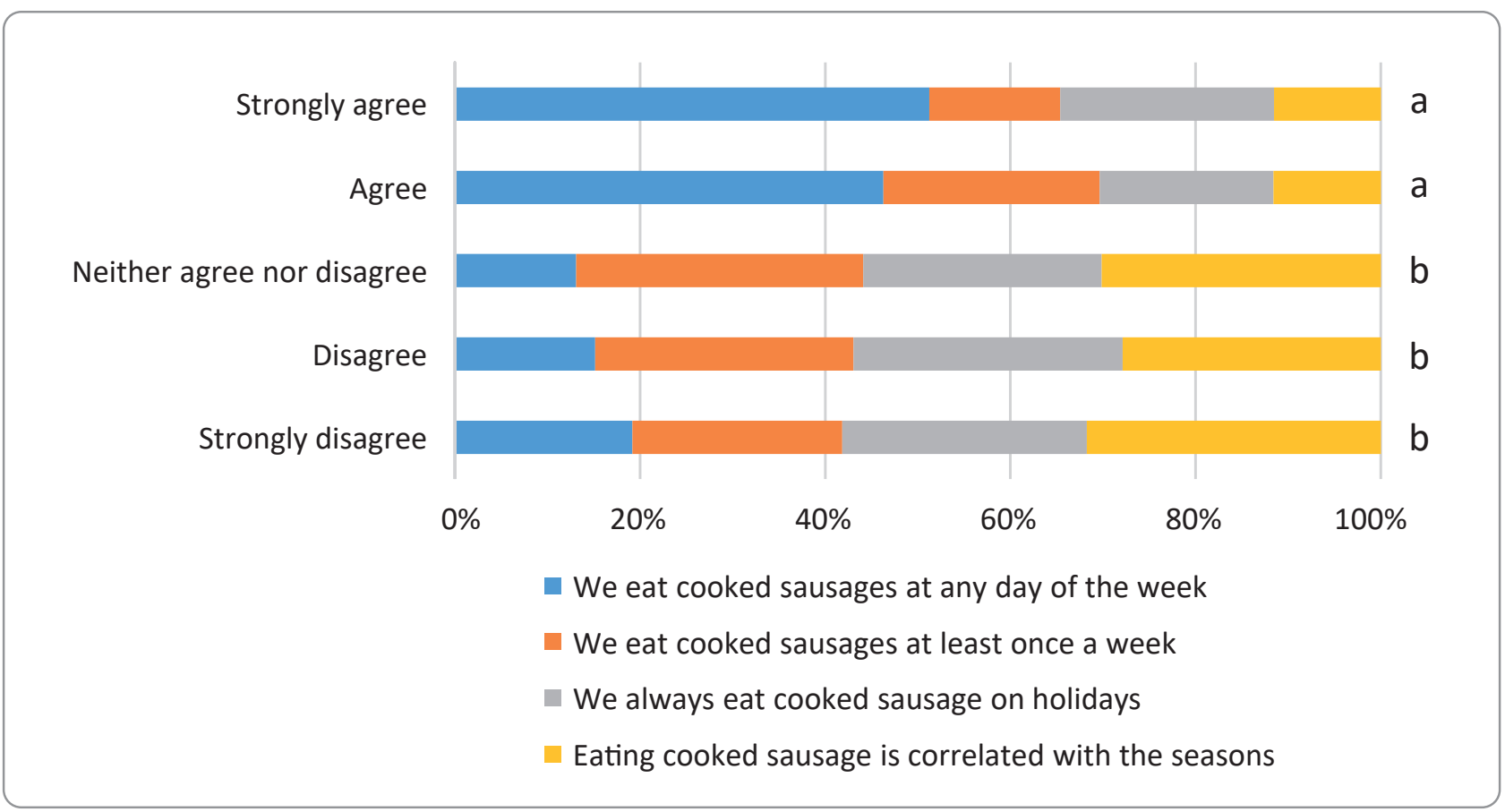

Figure 1. Frequency of cooked sausage consumption in households $(n=1,959)$. The different superscripts ${ }^{a-b}$ indicate significantly different levels of agreement at the 0.05 level.

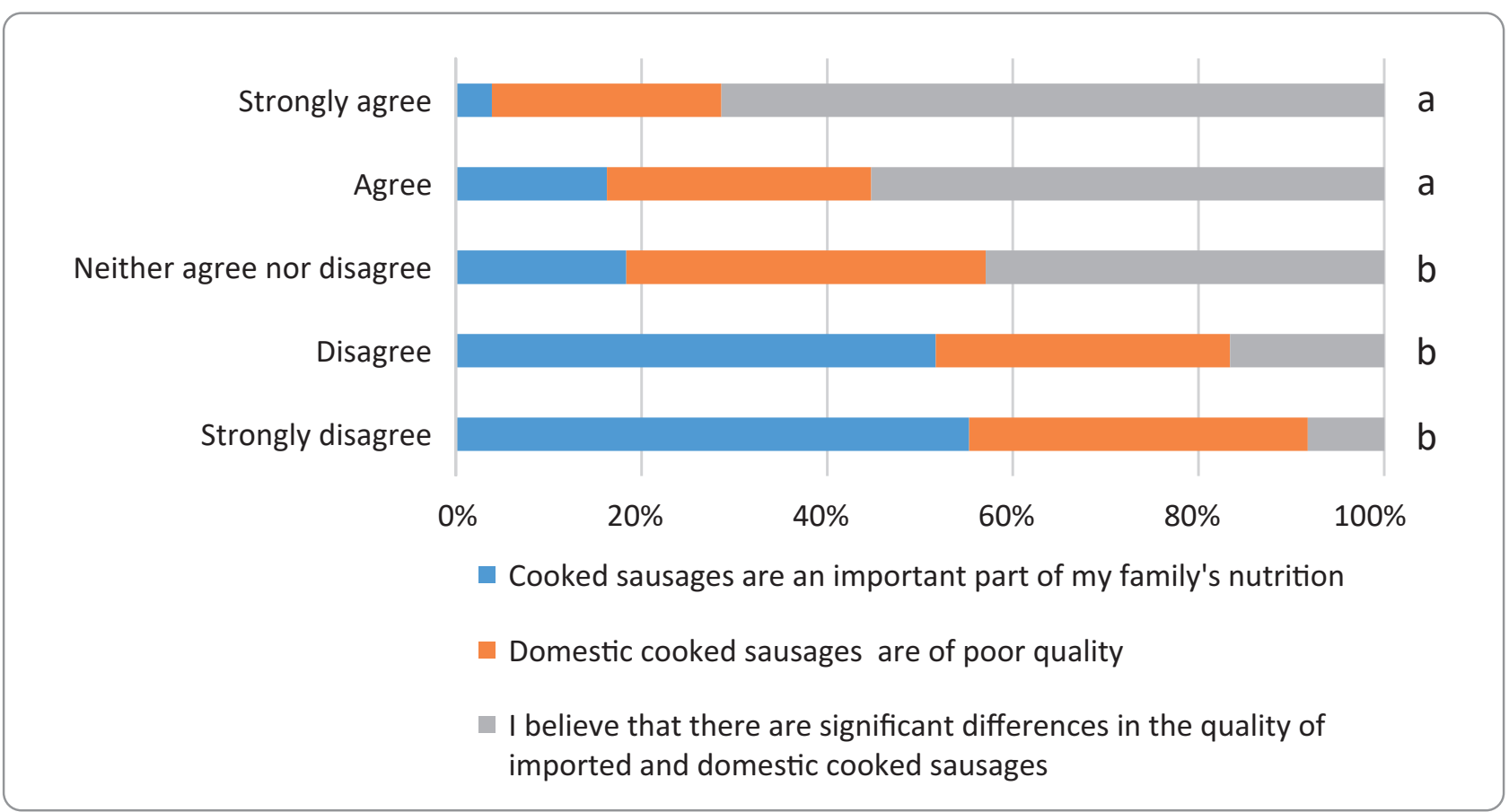

Figure 2. Commitment to buying cooked sausages $(n=1,959)$. The different superscripts ${ }^{a-b}$ indicate significantly different levels of agreement at the 0.05 level. 


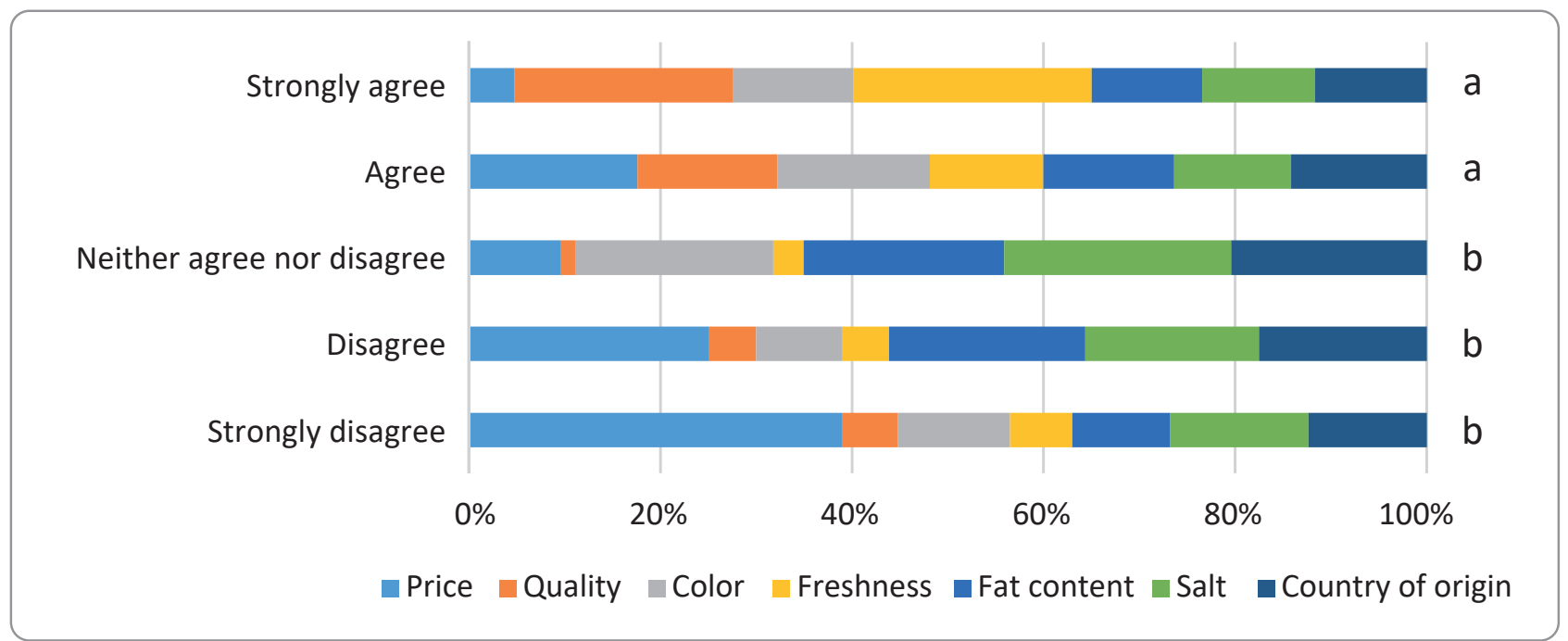

Figure 3. Reported buying behaviour for cooked sausages $(n=1,959)$. The different superscripts ${ }^{a-b}$ indicate significantly different levels of agreement at the 0.05 level.

al., 2018). According to Moskowitz (1995), it is not sufficient to motivate consumers with high quality standard information without adequate sensory properties in the sausage they are purchasing. Numerous authors (e.g. Pieniak et al., 2009) showed that the traditional character or image of local food is a relevant element affecting consumer purchasing decisions. Accordingly, in this study the geographical origin was an important consumer behaviour determinant.

\section{Conclusion}

The three most influential aspects affecting sausage consumer choice were perceived quality, salt content and freshness. This research could provide a novel approach (i.e. identification of the main aspects affecting consumers' purchase decisions and verification of product compliance to the identified determinants) to be followed for the study and promotion of other cooked sausages worldwide.

\title{
Stav potrošača i procena kvaliteta barenih kobasica u Srbiji
}

\author{
Vesna Đorđević, Tatjana Baltić, Danijela Šarčević, Ivana Branković Lazić, Jelena Ćirić
}

A p s tr a k t: Cilj ove studije je bio utvrditi stav potrošača i procenu kvaliteta barenih kobasica u Srbiji. Istraživanje sa 9 pitanja $u$ vidu ankete bilo je dostupno preko internet stranice, kako bi se analizirao stav potrošača o kvalitetu barenih kobasica. Upitnik je od oktobra do decembra 2018. godine popunilo 1.959 ispitanika. Pitanja su se odnosila na barene kobasice (hrenovke, pileće viršle, srpske kobasice, tirolske, pariske kobasice, Ekstra kobasice, kobasice Mortadela i kobasice Šunkarica); zatim o navikama konzumiranja barenih kobasica; tri pitanja su se odnosila na kupovinu barenih kobasica i jedno pitanje se odnosilo na ponašanja potrošača za kupovinu barenih kobasica. Rezultati pokazuju da većina srpskih potrošača konzumira pileće viršle otprilike jednom mesečno ili manje, a Šunkaricu otprilike jednom nedeljno ili manje (61.85\% i 28.48\%, pojedinačno). Potrošači su se u potpunosti slagali da konzumiraju barene kobasice bilo kog dana u nedelji. Potrošači su se uglavnom izjasnili da postoje značajne razlike u kvalitetu barenih kobasica iz uvoza i sa domaćeg tržišta.

Ključne reči: kobasice, Srbija, potrošnja, poznavanje potrošača.

Disclosure statement: No potential conflict of interest was reported by the authors.

Acknowledgments: This paper was supported by the Ministry of Education, Science and Technological Development, Republic of Serbia, through the funding of the Project: Selected biological hazards to the safety/ quality of food of animal origin and the control measures from farm to consumer (TR 31034), and the Directorate for Agrarian Payments (as a part of the Ministry of Agriculture and Environmental Protection). 


\section{References}

Girolami, A., Napolitano, F., Faraone, D., Di Bello, G. \& Braghieri, A. (2014). Image analysis with the computer vision system and the consumer test in evaluating the appearance of Lucanian dry sausage. Meat Science, 96, 610-616.

Janjic J., Katic V., Ivanovic J., Boskovic M., Dokmanovic M., Baltic, T. \& Baltic, M., (2015). Temperatures, cleanliness and food storage practices in domestic refrigerators. International Journal of Consumer Studies, 40, 276-282. DOI: $10.1111 / \mathrm{ijcs} .12252$

Meilgaard, M, Civille, G. V. \& Carr, B. T. (1999). Sensory Evaluation Techniques, 3nd ed. Boca Raton, Florida: CRC Press LLC, 231-234.

Mitic, V., Kilibarda, N., Brdar, I., Kostic, M., Sarcevic, D., Karabasil, N. \& Mizdrakovic, V. (2018). Measuring competitiveness in the meat industry market: Are there any oligopolies in Serbia? Meat technology 58(2), $127-136$.

Moskowitz, H. R. (1995). Food quality: conceptual and sensory aspects. Food Quality and Preference, 6, 157-162.
Official Gazette of the Republic of Serbia (2015; 2017).

Pieniak, Z., Verbeke, W., Vanhonacker, F., Guerrero, L. \& Hersleth, M. (2009). Association between traditional food consumption and motives for food choice in six European countries. Appetite, 53, 101-108.

Resano H., Sanjuán A. I. \& Albisu L. M. (2009). Consumers' acceptability and actual choice: An exploratory research on cured ham in Spain. Food Quality and Preference, 20, 391-398.

Santa Cruz M. J., Garitta L. V. \& Hough G. (2003). Note: Relationships of consumer acceptability and sensory attributes of Yerba mate (Ilex paraguariensis St. Hilaire) using preference mapping. Food Science and Technology International, 9, 346-347.

Sarcevic D., Djordevic V., Petronijevic R., Matekalo-Sverak V., Karabasil N., PopovicLj., Jankovic V., 2013. The attitudes and habits of Serbian school children in consumption of meat. Tehnologija mesa, 54, 2, 160-167.

Vukovic, I. (2006). Osnove tehnologije mesa, Veterinarska komora Srbije, Beograd.

Paper received: 3.12.2019.

Paper corrected: 17.12.2019.

Paper accepted: 17.12.2019. 